\title{
From the Workshop of J. J. Abrams: Bad Robot, Networked Collaboration, and Promotional Authorship
}

\author{
Leora Hadas \\ University of Nottingham
}

Whether 'New golden age' (Leopold, 2013) or 'Peak TV' (Paskin, 2015) whatever glowing accolades cultural commentators now choose to use, all describe television in the United States as going from strength to strength. For a sustained number of years now, critics and popular opinion alike has celebrated a qualitative transformation in the output of an industry that has struggled for years to shed the image of a 'vast wasteland' (Minow, 1961). In critical and academic circles alike, credit for these exciting developments and the transformation of US television has tended to focus on a specific feature of the contemporary industry: the figure of the showrunner, television's new auteur (Martin, 2013).

The emergence of the showrunner-as-auteur has provided US television with a crucial source of cultural legitimacy, one traceable back to Bourdieu's concept of the "charisma" ideology' (1980, p. 262) at work in judgements of artistic value. Shyon Baumann (2007) has analysed how film found legitimation as

How to cite this book chapter:

Hadas, L. 2017. From the Workshop of J. J. Abrams: Bad Robot, Networked

Collaboration, and Promotional Authorship. In: Graham, J. and Gandini, A. (eds.).

Collaborative Production in the Creative Industries. Pp. 87-103. London: University of Westminster Press. DOI: https://doi.org/10.16997/book4.f. License: CC-BY-

NC-ND 4.0 
an art form in the 1960s through the celebration of autonomous film artists. The showrunner fills for television the same function of elevating 'an artist of unique vision whose experiences and personality are expressed through storytelling craft, and whose presence in cultural discourses functions to produce authority for the forms with which he is identified' (Newman \& Levine, 2012, p. 38). Described as ' [a] curious hybrid of starry-eyed artists and tough-as-nails operational managers' (Collins, 2007), the showrunner takes the positions of both 'creative' and 'suit', acting as both the creative leader of a show - head writer, manager of the writers' room, ultimately responsible for plot and character decisions - and its executive producer, thus also being its representative and advocate with the network. The show is therefore presented as the expression of one person's singular, authentic vision, an exciting development from popular perception of television as entertainment by factory and formula, which have hounded the medium in the past (Mittell, 2015, p. 95).

As John Thornton Caldwell (2008) has argued in his tellingly named Industrial Auteur model, the creation of a television show is inevitably a complex collaborative endeavour, characterised by a multiplicity of voices. Auteurist discourse, however - to return to Bourdieu's observations - obscures the logic of production in the process of legitimation. Since the early 2000s, HBO has won fame, respect, and crucially also ratings by advertising the creative freedom it afforded early showrunners such as David Simon and Alan Ball, in comparison with broadcast television's unfortunate reputation for executive meddling (Feuer, 2007). The showrunner-auteur thus emerged as 'a branding strategy for upscale television as it contrasts the authored series against an undifferentiated mass' (Newman and Levine, 2012, p. 42). Nowadays, however, prominently visible showrunners are everywhere, on cable channels, broadcast networks, and netlets alike, in all cases serving in a similar auteurist capacity.

This has provided TV with its own 'commerce of auteurism', to paraphrase Timothy Corrigan (1991), in which author figures are deployed as a promotional device. In contrast with the traditional anonymity of TV creators (Pearson, 2011), today many showrunners are celebrities for whom the function of being the public face of their show is a crucial third hat alongside their roles as writer-producer. Increased visibility and ability to interact with viewers, for example through social and digital media, contribute to the association between visionary and vision. In this way they create a focal point for audience engagement, which can sometimes travel beyond the one show, as for example in the fans that have followed creator Joss Whedon from Buffy the Vampire Slayer (WB/UPN, 1997-2003) to Firefly (Fox, 2002). Similarly, shows marketed as the brainchildren of such creators advertise their names as a stamp of approval and quality, in fact a brand name (Mittell, 2015, p. 97). The showrunner figure thus stands at the core of contemporary American television's use of promotional authorship - the practice of applying author figures and authorship discourses for the branding, distinction, and marketing of content. Newman and Levine argue that in order to moonlight as auteur, it is usually necessary for the showrunner to also be the creator of the show (2012, p. 39). 
Increasingly, however, it seems that the showrunner-auteur pedestal is being shaken by structural and economic forces within the industry which render the model of creator-showrunner driving a single passion project increasingly unviable. On May 2014, following the announcement of greenlit new shows at Fox and NBC, Deadline reported that more than half of those shows were still without showrunners, and that networks were 'scrambling' to find showrunners for new series and often encountering difficulties in finding people with the appropriate background and experience (Andreeva, 2014). As original content online becomes more prevalent via services such as Amazon and Netflix, television networks attempt to keep up by turning to event programming and to short-form content that reject the seasons system and long-term seriality. Both these formats, with their appeal to respectability and the ideals of quality television, call for powerful showrunners and push the demand ever upward. Yet despite the Writers' Guild of America West running a showrunner training programme since 2005, showrunner supply continues to fall short. The sheer complexity and amount of responsibilities and functions involved in the role 'creative', 'suit', 'PR agent', and 'auteur' in one - mean that even decorated veterans of the industry are not necessarily qualified.

The industry abhors a vacuum, and in recent years American television production frequently sees new variations on the relationship between visionary and vision: shows swapping out showrunners, 'hired-gun' showrunners working on shows where they are not the original creator, and even shows marketed via the promotional authorship of a figure who is neither creator nor showrunner. However, auteurist ideas are powerful and entrenched, especially as they provide a counterweight to the traditional accusation, from Minow to Mittell, of television's creative poverty. Hence, as new models are deployed, they must grapple with the need to apply the auteurist discourse of singularity, creative control, authenticity, and vision to industrial realities of collaboration and complex work.

This chapter focuses on a particularly successful instance of such grappling, in which the practices of collaboration are brought back under the promotional aegis of auteurism through the application of what may be termed a master studio or workshop model of promotional authorship. As my case study I use one of contemporary American media's greatest author-brand names: J. J. Abrams, multihyphenate writer-director-producer of film and television, visionary leader of the tightly knit creative cabal that has emerged from his production company, Bad Robot.

\section{'When They Say It's a J. J. Thing, That's Cool with Me': Collaboration and subsumption}

J. J. Abrams has a long-standing reputation for repeatedly working with the same individuals both above and below the line. His collaborative practices date back to the transition from his first television series, Felicity (WB, 1998-2002), 
to his second, Alias (ABC, 2001-6), where he had brought with him actress Jennifer Garner and director Jack Bender. It was with his breakout hit Lost (ABC, 2004-10), however, that the trickle became a torrent. No less than six above the line crewmembers carried over from Felicity and Alias - Bender, producer Bryan Burk, writers Drew Goddard, Jeff Pinkner, and the writing partners Edward Kitsis and Adam Horowitz. Some seventeen Lost cast and crew members have gone on to collaborate with Abrams again, as have Felicity and Alias alumni that had no part in Lost, and others from Abrams' cinematic directorial debut Mission: Impossible III. Still others, such as Fringe (Fox, 200813) and Almost Human (Fox, 2013-14) showrunner J. H. Wyman, were picked up even later but have remained in the fold. The complicated task of mapping Abrams' collaborators results in 25 names that to date have moved in and out of his orbit, and the number grows when considering people who have collaborated with him and then gone on to work with his other collaborators in an ever-expanding game of six degrees of separation. While studies of media labour often emphasize the crucial importance of networking in Hollywood (see for example Hesmondhalgh and Baker, 2010), the repeated connections and overt identification of Abrams' collaborators with his brand ensures the 'cabal' stands out.

It is the nature of the collaborations, however, that distinguishes this clique from the practices and networks of other creators. The secret to Abrams' empire is the quintessential function of the author name as brand name, which allows a networked group of collaborators to present the image of a unified creative vision, and enjoy the legitimacy conferred through auteurist discourse. To speak of J. J. Abrams is to speak of his production company Bad Robot, which has delivered no less than 11 television series (plus three failed pilots, and three unaired pilots in the pipeline) to various networks between 2001-16, as well as producing 12 films. Abrams is credited as executive producer on each and every one of those projects, but it is hard to say how much direct involvement he has had in most of them. He has written a mere four of Bad Robot's films (Joy Ride (Dahl, 2001), Super 8, and writing credits as part of a team on MI:3 and Star Wars: The Force Awakens) and directed five (MI:3 and Super 8 once more, as well as the two Star Trek films and SW:TFA). On television his record is even spottier. He is credited as co-creator, writer, and director on his first two series, Felicity and Alias, and as co-creator of Lost, for which he co-wrote and directed the pilot. However, following this and the unaired pilot The Catch, he holds only executive producer credit on the vast majority of Bad Robot's projects - he is credited only as co-creator of Undercovers (NBC, 2010) and Fringe, to which he has contributed nine scripts in total, and no directorial involvement. The people claiming showrunner credit for Bad Robot's myriad shows are all Abrams' frequent and numerous collaborators: Damon Lindelof (Lost), Pinkner and Wyman (Fringe), Jonathan Nolan and Greg Plageman (Person of Interest, CBS, 2011-), Elizabeth Sarnoff and then Jennifer Johnson (Alcatraz, Fox, 2012), Wyman again on Almost Human and a succession of showrunners 
in the brief four-month life of Believe (NBC, 2013-14). Revolution (NBC, 2012-14) went one step further and employed a showrunner with his own significant claim to fame in the person of Eric Kripke, creator of the long-lived Supernatural (The WB/CW, 2005-).

It is in the promotion of Bad Robot shows, however, that all collaborating participants are rendered invisible, or at best are diminished. A look at the promotion of the studio's many shows reveals how, without fail, the focus is on Abrams, with even the name Bad Robot itself making very few appearances. The trend begins with Lost, where the season one DVD trailer announces the show to be 'from J. J. Abrams, the creator of Alias'. Fringe shows a mixture, advertised as 'from J. J. Abrams and the writers of Transformers Roberto Orci and Alex Kurtzman' in one trailer, and 'from J. J. Abrams creator of Lost and Alias' in another (Abrams' actual position as Lost co-creator is given a promotion). An NBC behind the scenes feature/trailer on Undercovers 'sum[s] up Wednesdays [when the show is due to air] in two words [...] "J. J." - neglecting even the director's surname, on the assumption that the audience will know who 'J. J.' is - and the show's other promos all mention Abrams and omit cocreator Josh Reims. Trailers for Person of Interest deign to mention creator Jonathan Nolan as the screenwriter of The Dark Knight. However, their overall tone is better exemplified by the promo starring the cast of The Big Bang Theory (CBS, 2007-), which glosses over Nolan's involvement before excitedly namedropping half a dozen past Abrams projects. The Alcatraz trailers mention 'executive producer J. J. Abrams' and the nameless 'producers of Lost', while that of Revolution mentions pilot episode director Jon Favreau besides Abrams but leaves out Kripke. An especially telling absence is that of the one collaborator who has, in fact, been present for all of Abrams' projects: Bryan Burk, Bad Robot's co-founder and executive vice president. Burk's complete invisibility, in spite of the fact that he shares executive producer credit with Abrams on all Bad Robot shows, serves to drive home the fact that the careful construction of promotional discourse is intrinsic to the auterism of Bad Robot shows.

Subsumption is a key part of auteurist discourse, which relies on an immediate, intimate connection between auteur and artwork: it is perfectly run-ofthe-mill for the author's name to stand in for the dozens or hundreds of people working on a movie set. Yet here, uniquely, one creator's name brings together a constellation of projects that have no connection beyond the presence of that name. This is even a degree removed from the 'authorship by management' that Mittell refers to as typical of the showrunner's work, which 'filter[s] the contributions of performers, designers, editors, and network executives, but the responsibility for the end product rests with the showrunner' (2015, p. 91). Abrams himself admits that he is hands-off with the work of other creators under the Bad Robot banner, saying 'When we hear a pitch we like and develop a show [...] we don't get involved with people who need to be babysat.' (Molloy, 2013) In the end, however, it is his signature that is touted in the promotion of the project and connects it to the exalted family of other projects that bear the 
same signature as their authenticating mark and proof of lineage. His name, as a selling point and a promise, obscures the involvement of other creators and creates the illusion of a genius that is a bottomless creative font. Being tied directly to various projects allows him to legitimise them all as works of equal standing, regardless of his differing level of involvement. As Wyman himself puts it, 'just from the sale aspect, he's such a force to be reckoned with [...] when they say it's a J. J. thing, that's cool with me' (ibid).

Yet Abrams must also be cautious with his brand name, as we learn from the trailer of the Bad Robot produced Morning Glory (Michel, 2010), from which Abrams' name is conspicuously absent. Morning Glory, a comedy with neither fantasy elements nor any central mystery, was advertised as 'from the screenwriter of The Devil Wears Prada' and 'the director of Notting Hill', both left nameless, so that neither director Roger Michel nor Abrams get direct credit. It seems that Abrams' producer credit had no place in promoting a movie so removed from his usual fare, identifying the limit point of the brand name. The projects that are brought together under Abrams' aegis do all have something more in common: a broad generic definition as telefantasy and, as I discuss further, an emphasis on a storytelling and pop cultural sensibility. Functioning as a brand name, Abrams' name must guarantee a certain known set of qualities. Without doing so, it is displaced and meaningless.

\section{'The J. J. Abrams Business'}

Abrams' involvement as producer supersedes the more standard ascriptions of authorship in both film and television, where it is normally the director and showrunner respectively who are understood to have the most creative control. The promotion of Bad Robot shows complicates the centrality of the showrunner-auteur to the post-network era as discussed for example by Emily Nussbaum (2009). Even the 2013 edition of The Hollywood Reporter's top showrunners list refers to Jonathan Nolan and Greg Plageman (Person of Interest) and Eric Kripke (Revolution) as 'Team J. J. Abrams', complete with Abrams's photo (THR Staff, 2013). This shift in focus suggests that, while there is indeed greater visibility of television creators and an increasingly prevalent idea of creative leadership in television, the question of who takes credit for this leadership is still being contested.

Series where the promotional authorship function of the showrunner is overtaken by the brand name of a producer are uncommon but not unknown. Television is following in the footsteps of film in this regard, where directorsturned-producers from Spielberg to Tarantino, as well as superstar producers such as Jerry Bruckheimer, have a long history of 'presenting' a film. The Hollywood Reporter's 2013 list featured two more 'teams' following the similar logic of an executive producer and studio head overseeing a number of shows each run by its own creative team of current and former collaborators. 'Team Chuck 
Lorre' in the comedy category is composed of Don Reo and Jim Patterson on Two and $a$ Half Men (CBS, 2003-15), Steve Molaro on The Big Bang Theory, Al Higgins on Mike \& Molly (CBS, 2010-) and Eddie Gorodetsky on Mom (CBS, 2013-). 'Team Greg Berlanti' in drama includes Andrew Kreisberg and Marc Guggenheim on Arrow (The CW, 2012-) and Phil Klemmer on The Tomorrow People (The CW, 2013-14).

In both cases, the situation differs somewhat from Abrams', as evidenced by the lesser presence granted to either men in the official promotion of their associated shows: while popular in the press, neither get name credit and are only mentioned in terms of previous successes in trailers. Use of their names is inextricable from an association with a particular network, as well as conditional upon other factors. Lorre, an active television producer since the early 1990s, rightly belongs to an earlier generation of producers and has had a significantly longer time to build up his presence in the industry, while Berlanti is tied to the 'Arrowverse', The CW's shared televised universe based on DC Comics properties. Nonetheless, the decision by The Hollywood Reporter to present them in similar templates suggests the emergence of a new paradigm.

The thinking here is no longer in terms of the single show, its production and creative leadership, but in terms of ownership of 'a whole block of programming', as the list says. The role of showrunner is not necessarily reduced in responsibility, as shows still have to be run on a day to day basis, yet the emphasis in promotional discourse - on brand name and creative visionary - shifts to the head of the production studio, or the central node of the collaborative network. In the case of Abrams, this shift is tied in with the search for larger and more expansive franchises and for brands that operate across media. Here is a form of authorship suitable to an industry that thinks in terms of conglomeration, horizontal integration, and large-scale exploitation of assets. The commercial imperative for broadly transferrable IP, across projects and platforms, is already understood as standard media industry practice, for example with Marvel Studios announcing itself as being 'not in the movie business, we're in the "Iron Man" business right now' (Boucher, 2008). Here, similarly, NBC can announce itself to be 'in the J. J. Abrams business' (Rose, 2011), with the author name acting as an exploitable, transferrable brand.

The showrunner's position of absolute creative authority, in this scenario, takes on the cast of a property manager. This is not however to reduce the showrunner position to merely executing another's vision, which would undermine the auteurist discourse on which its promotional function is based. The Hollywood Reporter frames Nolan, Plageman, and Kripke as his 'primetime partners', which in turn plays a key part in their ability to arrive and stay on air. The relationship between the creative leadership of a show, and the brand power that it relies upon in its relationship with both industry and audiences, grows more complex. However, unlike the normal tension evident between 'creatives' and 'suits', this relationship between showrunner and brand-name producer is not characterised by an oppositional dichotomy between art and commerce, 
authenticity and executive meddling. If anything, the power of Abrams' bankable name and the Bad Robot affiliation create a buffer between the showrunners on individual shows and their network overseers. Despite differences of rank, Abrams and 'his' showrunners portray themselves very much as collaborators, making extensive use of a language of meeting of minds and similarity of interests, as well as stressing cooperation as a creative ethos. As Variety describes it in a 2009 article about Abrams' 'fanboy family':

Abrams, Kurtzman, Orci, Lindelof and Burk spent many hours together hashing out the basic story for the Star Trek reboot - knowing what a tricky assignment they had on their hands - while Kurtzman and Orci would bring the group pages to review as they progressed on the screenplay. [...] Says Orci: "The best idea wins. Collaboration wins. It's not about individual achievement when we get together." (Littleton, 2009)

The article, a lengthy feature on Abrams and co., provides an overview and a discursive framework of creative relationships not only within Bad Robot, but throughout the network of media creators that '[speak] Abrams' language, a dialect of Star Wars, comicbooks, Steven Spielberg's canon, The Twilight Zone, Super Mario Brothers, Stephen King and other common influences and obsessions. This list of influences suggests the qualities of Abrams' author brand science fiction and fantasy, adventure, geekdom, and a kind of pop culture nostalgia - which he himself has articulated on multiple occasions, for example his 2007 TED talk (TED2007, 2008). All of these are now described as essential parts of his collaborators' identities, as much as they are part of his. Variety continues to stress the cohesion of the group:

Out of such shared visions, the Abrams footprint has expanded from TV to film, with his productions proving to be a wellspring of writers, directors and producers who have become major biz players in their own right. He's been a magnet for like-minded creatives who share his professional DNA [...] While Abrams' alumni now have no shortage of opportunities separately, they remain a tightly knit creative cabal that continues to work frequently with one another. [...] "What's made us all come together in a way is that we recognize each other as longlost brothers", Kurtzman says of his and Orci's strong connection with Abrams and Lindelof. "We were influenced by the same things growing up. [...] We come to story from a similar place." (Littleton, 2009)

The emphasis on authentic personal and creative connection serves to defuse issues of power and characterise all involved in the role of 'creatives', regardless of the nature of their involvement with individual projects. It functions well to erase, or at least obscure, questions of individual self-expression by rendering 
all participants as sharing a mind-set, a set of interests and obsessions that replenishes the creative font. Though the family 'fans out', their shared core values make them able custodians of each other's ideas. Part of Abrams' reputed talent, and as such his brand, becomes the ability to choose his collaborators, verify, and ultimately vouch for their suitability to the creative network. His role includes the maintenance of a coherent vision and image for the whole family, something that can be seen in the language of training often used to describe his collaborative relationships. The Variety feature used the term 'Abrams alumni' and references the 'lessons learned' on his shows by creators who have since ventured out on their own. In the network of mostly-equals that results, Abrams is able to function as a central node. He need not be personally involved in the collaboration at all. As Edward Kitsis says:

We've become great friends with a lot of people who've worked on other J. J. projects [...] Even if you've never worked with them, you can call them up and say, "Can I get your opinion on something?" (Littleton, 2009)

It almost goes unsaid that there results a distinct creative identity for Bad Robot, a house style of sorts that informs audience expectations and understanding. It is likely no coincidence that the most successful Bad Robot shows seem to share the 'mystery box' style of storytelling that Abrams emphasizes in his TED talk as key to his work. All share a reliance on a central mystery and a multi-layered, hyper-complex narrative full of leads, clues, and red herrings. Fringe, Person of Interest, and Revolution, the three Bad Robot shows that have so far enjoyed the longest runs, all followed this formula, with similar characteristics in their premise of cutting edge technology gone awry and modern fears of science, surveillance, and technological dependence. Abrams applies this logic in his attempt to justify the failure of Undercovers, telling Seriable:

The conceit of the show was to do a much more frivolous, fun show, but ultimately, I think it was just too frivolous and too simple, and we didn't go deep enough. We were really desperately trying to stay away from mythology and complexity and intensity and too much serious, dark storytelling and, ultimately, that's not necessarily what I do best. I think audiences felt that it was a little bit lacking. (Roco, 2011)

Abrams' explanation hinges on the idea that the studio had strayed outside its comfort zone, and that the audience was naturally not receptive to a Bad Robot show that was 'desperately trying' to eschew the Bad Robot brand qualities of complexity and mythology. There are a number of other aspects to the network's creative identity, which Abrams and others have outlined clearly: high concept science fiction and fantasy, a mixture of action and emotion, a drawing on pop cultural resources and particularly early blockbuster films. Yet the 
central element that dates back most famously to Lost - but was already present in Alias - is the convoluted mystery and mythology. It is notable as such that this of all elements is the one most personally associated with Abrams himself. The mystery box as a metaphor for storytelling is the closest thing to Abrams' personal signature, and serves as the guiding vision by merit of which he claims ultimate creative ownership of, and presence in all (successful) Bad Robot productions. Wherever there is a narrative mystery box, Abrams is present, regardless of whether his title is in the credits. ${ }^{1}$

This combination of a unified, auteurist creative identity on the one hand, yet a dispersed network rather than a corresponding absolute hierarchy on the other, distinguishes Bad Robot from the similar model of corporate authorship found in film production studios of brand-name directors, such as Steven Spielberg's Amblin Entertainment or Francis Ford Coppola's American Zoetrope. Coppola and Spielberg have been known to append their names as promotional devices to films either produced or released by their companies. Both have also produced the films of other brand-name directors: for example, Coppola with Bill Condon with Kinsey (2004) and Tim Burton with Sleepy Hollow (1999), and Spielberg with Joel and Ethan Coen's True Grit (2010) and of course Abrams himself with Super 8. What no studio in this model has done is create a cohesive network of repeated collaborations, which is then capable of being branded throughout by its association with its central node. While Spielberg and Amblin did, for example, work with Clint Eastwood on four of his films, it would be hard to argue for Eastwood being a part of a Spielbergcentric network - and harder to think of the two as sharing a creative signature. ${ }^{2}$ Nor have any of the directors mentioned above been known to 'delegate' in the manner of Abrams, who for example was billed as the original creator of Lost, directed its pilot episode but then subsequently passed showrunning duties on to Damon Lindelof and Cartlon Cuse. Therein lies the critical differences between the author-company brand and Bad Robot's network-company brand.

Models of corporate authorship have, indeed, been explored before in both the film and television industries, in a number of studies that have sought to challenge auteurism as a discourse. Considering film, Thomas Schatz (1998) has written of 'The Genius of the System' of early Hollywood, while Jerome Christensen (2011) has argued for film as a 'corporate art', drawing attention to the studio brand. Similarly in television, The Mary Tyler Moore Show has been considered as primarily a studio product (Feuer et. al., 1984). It is, however, on the promotional side that Abrams and Bad Robot show the unique model of a continued appeal to auteurism, embodied in the studio head, combined with the use of a stable of individual talents working on individual, unconnected projects. A more useful model to compare with Abrams' 'fanboy family' may be found not in the companies of either classical Hollywood moguls or New Hollywood auteurs, but much further back in the past, with different brand name creators altogether. 


\section{Models old and new: The Renaissance workshop and the production studio}

It is useful not only to consider Abrams and Bad Robot within the framework of the future of the media industries, but also to historicize this unique emergent model in relation to older models of creativity. As mentioned, the studios of brand-name Hollywood directors offer only a limited comparison for understanding the operation of such networked promotional authorship. Instead, we might look at another kind of studio model, which has the added distinction of having emerged around the same time that the concept of individual creative genius, and its accompanying charisma ideology, was budding in the West. This is the Renaissance bottega: the master's studio or workshop. Modern workshop models, such as those of Andy Warhol's Factory or the William Morris Company, offer more recent takes on the same concept. Yet looking at the bottega in its original historical context allows the analysis to provide perspective on the interaction between he emergence of modern authorship discourses, and the shape and functionality of collaborative production.

Much of the scholarship of Renaissance fine art focused on exalting the work of solitary masters: such 'Renaissance Men' as Da Vinci, Raphael and Michelangelo who provide the model for the genius artist. We know, however, that actual working practices in the Renaissance were in fact much more collaborative and even corporate, making extensive use of hands other than the master's own. According to historian Peter Burke, when paintings produced in the workshop were signed, 'the function of the signature was probably to guarantee the product rather than to express the pride of an individual creator' (Burke, 1994, p. 3).

Standard practice in Italian Renaissance art saw the master painter oversee a workshop, populated by apprentices, assistants, and specialized workers of varying ranks. Though apprentices were educated in those workshops, their role was considerably more important and involved than merely adding in flourishes or backgrounds. Rather, they were frequently responsible for the execution of central figures and scenic compositions (Maginnis, 1995). Apprentices and assistants were required to practice the master's brush so that 'the apprentice's idiom would become indistinguishable from his teacher's' (Cole, 1995, p. 89), in order to allow for a seamless product to emerge from a process that was essentially corporate. The junior artists within a workshop were not employed solely in working on the master's commissions, but were able and even encouraged to take on commissions of their own. As Anabel Thomas writes:

It was normal workshop practice for assistants to accept orders independently. [...] Established masters might be recruited as assistants to a separate major project, the management of which might be in the hands of another workshop. [...] Workshop assistants, for their part, could and did secure commissions in their own right, in other words as "masters" (Thomas, 1995, p. 2). 
While some apprentices 'graduated' from their master's workshop and opened shops of their own, others might remain under the workshop's aegis for years as workers both independent and corporate. Artists running large workshops with a number of such workers at their disposal might take large-scale commissions where they would direct and supervise the work rather than carrying it out themselves (Burke, 1994). Graduates who have gone independent might return to workshops in which they have trained, and collaborate with their former master or, indeed, work under him on individual projects. References to old workshop associations can be seen to appear in contractual agreements (Thomas, 1995): patrons might ask an artist who has worked in a certain shop to paint in the style of his former master, or indeed even copy his work sometimes in collaboration with that same master (Cole, 1995).

This independence had its limits, however, as the workforce of a shop was encouraged to maintain a consistent 'house style', often through reproduction of previous merchandise. Burke (1994: 3) continues to note that 'it was the bottega rather than the individual which had a style'. Thomas (1995) adds, 'Renaissance workshop apprentices were trained to work towards a consistency of style rather than to place their own particular mark on those parts of the shop's merchandise with which they were involved.' (p. 213) The workshop thus had a creative signature - in effect, its brand. This derived from the style of the master, which the apprentices had trained to copy, and increasingly became tied to his signature. In the mid-sixteenth century, Titian, who was in high demand among continental nobility, was sanctioning use of his signature on pieces produced by his workshop in order to authenticate them (Cole, 1995).

The image of Bad Robot as a Renaissance studio is easy to conjure up, and elucidates the advantages that the model provides for different agents within it. Abrams acts as the master, setting the tone, creating the composition, and authenticating with his signature, his name metonymic to the studio. Finished works are, to take a common style of reference to Renaissance paintings, 'from the workshop of J. J. Abrams'. However execution is often in the hands of his apprentices and assistants, each of whom may act as the master in their own right on certain commissions. All are propped up by the reputation of the studio, and work within its house style, creating works that are consistent regardless of whose hand has produced which of their parts or even their entirety. Apprentices who branch out into studios of their own, such as Roberto Orci and Alex Kurtzman with K/O Paper Products, remain associated with the master's studio and often collaborate with or employ other apprentices. Orci and Kurtzman do this for example on Sleepy Hollow, employing actors John Noble (Fringe) and John Cho (the Star Trek film) and producer Ken Olin (Alias).

While attempts have been made to emulate the Renaissance workshop in the modern production of fine art, there is nothing to indicate that the similarity is conscious on Abrams' part. More likely, the model has returned as conditions demanded it. Hence, noting the resemblance allows us to consider key aspects of commonality between the contemporary US television industry and the fine 
art 'industry' of sixteenth-century Italy, particularly around the dynamics of cultural legitimation and the creation of new cultural producers as legitimate artists. This, in turn, allows insight on the market and labour conditions that shape authorship discourses around individuality and collaboration. One such condition may be an emerging need for an apprenticeship system for the education of showrunners. The range of skills required from a showrunner is wide, at times contradictory, and frequently more than the sum of its parts - which is to say, more than a mere extension of production and writing. Perfectly competent producers, writers, or managers of a writers' room may still prove unable to fill the position; the only real training for showrunnership, it seems, is in actually running a show. Failure rate in the television industry is extremely high; most new pilots never make it to series, so that the industry offers much fewer opportunities to gain showrunner experience than it opens demand for people who possess it.

As the discursive and promotional centrality of the showrunner outpaces the supply of capable individuals, there is a vital need for some system to both increase opportunities available and to mitigate the risk of failure. I mention above how former Bad Robot employees cite the pedagogical aspects of studio life, the lessons learned under Abrams the master. As part of the studio, producers and writers are able to amass experience on different projects, and finally to take their own commissions - create and run their own shows - with the backing of that studio as a safety net of sorts. Within the studio structure, in which best practices are already entrenched and experienced support available, an aspiring showrunner can work as executive producer on a number of projects before taking such front of house responsibility. Indeed this has been the pattern with a number of Bad Robot showrunners such as J. H. Wyman and of course Orci and Kurtzman.

The association with the studio brand also works to ease a burden that is unique to the showrunner role and causes particular difficulties - the need to manage a new visibility of what has in the past been a behind the scenes job. Showrunners in contemporary television must be not only competent writers and producers, but also competent celebrities, handling press and audience attention and acting as the face of their shows (Cuse, 2012). It has by now become not only common but expected of showrunners to engage with their audience via promotional devices such as podcasts and behind the scenes features, and through social media, with all the PR pressure and dangers involved (Newman and Levine, 2012; see also McNutt, 2016). The attachment to the established name of the studio's master reduces this pressure to perform and allows a showrunner the possibility of success without creating and maintaining an individual brand. This is yet another means for the reduction of risk in the unstable and project-based work environment of the industry. Working within a studio allows one person's name and reputation to secure the position of many. According to Anabel Thomas (1995, p. 2), the key ability of the Renaissance master was 'to sustain a workshop organization economically by 
generating a viable income through securing and dispatching business'. Variety's description of networks clamouring to join the 'Abrams business' gives a vivid image of how the master's ability to generate business for their studio works in contemporary television.

It is equally worth considering the studio brand in light of the development of the Renaissance workshops' house styles. In both cases, the maintenance of a coherent style led by the master allows for that master's reputation to continue working in its brand capacity, as a guarantor of quality and assurance to the customer of what they would be getting. As Mittell notes, 'identifying the creators of a new series can serve [...] functions of creating common audiences and branding' (2015, p. 97), and fans will frequently follow the auteur between shows. Yet in both cases it also operates to allow the work of many to pass for the work of one. Abrams on his own is no more able to run all of Bad Robot's shows than Titian was able to personally paint all his commissions. Just as the maintenance of a workshop allowed the nobility of Europe to declare their mutual status by possessing paintings by Titian, so the Bad Robot model allows the Abrams brand to be dispersed while maintaining its power, allowing different networks the prestige of owning Abrams shows. The gathering of a group of creators united by a proven stylistic signature, legitimised by the master's actual signature - even if merely in the form of a name on the credits list- is very convenient for patrons as well, allowing them to get more mileage out of the brand and cheat the auteurist demand for 'one man alone.' This offers another way to ease if not solve the problem of the showrunner shortage, and is especially useful as increasingly, in Denise Mann's words, showrunning is 'not TV, it's brand management' (2009, p. 97).

Sixteenth-century Italy is where the roots of the concept of the genius artist lie. Although it would only come into its modern form with nineteenthcentury Romanticism, interest in and reification of the 'master' appears already in Giorgio Vasari's canonical Lives of the Most Excellent Painters, Sculptors, and Architects, published 1550. Yet as the above example of Titian shows, the interest in the artist's signature also led to more demand for said signature than the artist himself could satisfy, inviting the answer of the workshop model. US television is now in a position curiously similar to Renaissance Italy, with focus turning to its own masters to validate it as an art form. It stands to reason then that a studio model has re-emerged, to allow those masters to sate the demands of the market for their authorised work.

The master workshop model of promotional authorship, much like any model in an industry facing as constant and rapid change as the television industry, must be seen in context as emergent and competing rather than established. In 2015, while J. J. Abrams was breaking cinematic records with Star Wars: The Force Awakens, Bad Robot had disappeared from the Hollywood Reporter list of 50 Power Showrunners. Yet at the same time, showrunners signed on to more than one or even two shows have become increasingly visible, making up a full 
fifth of the list (O'Connell and Hunt, 2015). Some, such as Abrams collaborator Carlton Cuse, and Greg Berlanti in a return appearance, seem to be following in the footsteps of the model. Others represent competing possibilities, inviting further research into the transmutations of promotional authorship in television under the pressure exercised by the introduction of auteurism. Bad Robot's success with the master workshop model shows that while the discourse at the heart of auteurism is consistent, traceable back through cinema to nineteenthcentury Romantic authorship, its expressions are flexible and its uses manifold. We are likely to see it continue to evolve.

\section{Notes}

${ }^{1}$ If one were unkind, one might point out that it is quite convenient for Abrams that his role only calls for him to place the closed mystery box. The opening of said box, which Abrams himself confesses is inevitably disappointing, is left to individual showrunners to take either the credit or the fall for - and it is often a fall. It was Damon Lindelof and Carlton Cuse who bore the brunt of the audience's frustration following the Lost finale. Being very kind myself, I leave such speculation to the footnotes.

2 There may be more room for comparison with Zoetrope producing Sofia Coppola's films, yet of course the family connection muddies the water considerably.

\section{References}

Andreeva, N. (2014). Showrunners wanted: Networks grapple with lack of experienced writing producers. Deadline, 7 May Retrieved from http:// www.deadline.com/2014/05/showrunners-wanted-networks-grapplewith-lack-of-experienced-writing-producers/

Baumann, S. (2007). Hollywood Highbrow: From Entertainment to Art. Princeton, NJ: Princeton University Press.

Bennett, T. (2014). Showrunners: The Art of Running a TV show. London: Titan Books.

Boucher, G. (2008). Marvel is on a mission. Los Angeles Times, (9 March. Retrieved from http://www.latimes.com/entertainment/la-ca-marvel9mar09,1,2967693. story.

Bourdieu, P. (1980). The production of belief: Contribution to an economy of symbolic goods (R. Nice, Trans.). Media, Culture and Society, 2, 261-93.

Burke, P. (1994). The Italian artist and his roles. In Peter Burke (Ed.), E. Bianchini and C. Dorey (Trans.) History of Italian Art, Volume One. Cambridge: Polity Press. 
Caldwell, J. T. (2008). Production Culture: Industrial Reflexivity and Critical Practice in Film and Television. Durham, NC: Duke University Press.

Christensen, J. (2011) America's Corporate Art: The Studio Authorship of Hollywood Motion Pictures. Stanford, CA: Stanford University Press.

Cole, B. (1995) Titian and the idea of originality. In A. Ladis and C. Wood (Eds.) The Craft of Art: Originality and Industry in the Italian Renaissance and Baroque Workshop (pp. 86-112) Athens: University of Georgia Press, 1995.

Collins, S. (2007). Who really runs things. Los Angeles Times, 23 November. Retrieved from http://articles.latimes.com/2007/nov/23/entertainment/etchannel23.

Corrigan, T. (1991) The Commerce of Auteurism. In A Cinema Without Walls: Movies and Culture after Vietnam (pp. 101-36.) New Brunswick, NJ: Rutgers University Press, 1991.

Cuse, C. (2012). Lost's Carlton Cuse relives dealing with the modern celebrity of the TV showrunner. Vulture, 19 October. Retrieved from: http://www. vulture.com/2012/10/carlton-cuse-lost-showrunner-celebrity.html.

Feuer, J. (2007). HBO and the Concept of Quality TV. In J. McCabe and K. (Eds.) Quality TV: Contemporary American Television and Beyond (pp. 145-57). London: IB Tauris.

Feuer, J., Kerr, P., \& Vahimagi, T. (Eds.) (1984). MTM: "Quality television”. London: BFI Publishing.

Hesmondhalgh, D. \& Baker, S. (2011). Creative Labour: Media Work in Three Cultural Industries. Abingdon and New York: Routledge.

Hibberd, J. (2013). "Almost Human": J.J. Abrams answers 8 burning questions. Entertainment Weekly, 15 November. Retrieved from http://insidetv. ew.com/2013/11/15/j-j-abrams-almost-human-interview.

Leopold, T. (2013). The new, new TV golden age. CNN Entertainment, 6 May. Retrieved from http://edition.cnn.com/2013/05/06/showbiz/golden-age-oftv/

Littleton, C. (2009). Fanboy family fans out. Variety, 461, 1-2, 19 October

Maginnis, H. B. J. (1995). The Craftsman's Genius: Painters, Patrons and Drawings in Trecento Siena. In A. Ladis and C. Wood (Eds.) The Craft of Art: Originality and industry in the Italian Renaissance and Baroque Workshop (pp. 25-47). Athens: University of Georgia Press.

Mann, D. (2009). It's Not TV, It's Brand Management TV: The Collective Author(s) of the Lost franchise. In V. Meyer, M. J. Banks and J. T. Caldwell (Eds.), Production Studies: Cultural Studies of Media Industries (pp. 97-114). New York: Routledge.

Martin, B. (2013) Difficult Men: Behind the Scenes of a Creative Revolution: From the Sopranos and The Wire to Mad Men and Breaking Bad. New York: Penguin Press.

McNutt, M. (2016). When fan engagement goes wrong. A.V. Club, 4 April. Retrieved from http://www.avclub.com/article/when-fan-engagementgoes-wrong-234346. 
Minow N. N. (1961). Television and the Public Interest. Address to the National Association of Broadcasters, 9 May Washington, DC.

Mittell, J. (2015). Complex TV: The Poetics of Contemporary Television Storytelling. New York: New York University Press.

Molloy, T. (2013). How much does J.J. Abrams do on a J.J. Abrams show? The Wrap, 14 November. Retrieved from http://www.thewrap.com/j-j-abramstv-shows-almost-human-how-involved-star-wars/.

Newman, M. Z. and Levine, E. (2012). Legitimating Television: Media Convergence and Cultural Status. New York: Routledge.

Nussbaum, E. (2009). When TV became art. New York Magazine, 4 December. Retrieved from http://nymag.com/arts/all/aughts/62513/.

O'Connell M. and Hunt, S. W. (2015 October 14). The most powerful showrunners 2015. The Hollywood Reporter. Retrieved from http://www.hollywoodreporter. com/lists/top-showrunners-powerful-executive-producers-831725/item/ jack-amiel-michael-begler-greg-831742.

Paskin, W. (2015). What does "peak TV" really mean? Slate, 23 December. Retrieved from http://www.slate.com/articles/arts/tv_club/features/2015/ best_tv_of_2015_slate_s_tv_club_discusses/what_does_peak_tv_really_ mean.html.

Pearson, R. (2011) Cult Television as Digital Television's Cutting Edge. In J. Bennett and N. Strange (Eds.), Television as Digital Media (pp. 105-31) Durham, NC: Duke University Press, 2011.

Roco (2011). J.J. Abrams explains why "Mythology-lite" Undercovers failed. Seriable, 16 January. Retrieved from http://seriable.com/jj-abrams-explainswhy-mythology-lite-undercovers-failed/\#ixzz3HomPht1R.

Rose, Lacy (2011 September 25). J.J. Abrams, "Supernatural” creator sell thriller to NBC. The Hollywood Reporter. Retrieved from http://www.hollywoodreporter.com/news/jj-abrams-supernatural-creator-sell-239996.

Schatz, T. (1988). The Genius of the System: Hollywood Flmmaking in the Studio Era. New York, NY: Pantheon Books.

TED2007. (2008 January). J. J. Abrams: The mystery box. Retrieved from http:// www.ted.com/talks/j_j_abrams_mystery_box.html.

THR Staff (2013 16 October). The Hollywood Reporter names the 50 power showrunners of 2013. The Hollywood Reporter. Retrieved from http://www.hollywoodreporter.com/lists/hollywood-reporter-names50-power-648546.

Thomas, A. (1995). The Painter's Practice in Renaissance Tuscany. Cambridge: Cambridge University Press. 
